\title{
The Importance of the Student Worksheets of Electronic (E-LKPD) Contextual Teaching and Learning (CTL) in Learning to Write Description Text during Pandemic COVID-19
}

\author{
Rosa Andria Syafitri ${ }^{1, *}$ Tressyalina $^{1}$
}

\author{
${ }^{1}$ Indonesian Language Education Study Program, FBS Universitas Negeri Padang, Padang, Sumatra Barat 25131, \\ Indonesia \\ *Corresponding author. Email: rosaandria46@gmail.com ${ }^{l}$
}

\begin{abstract}
To confront of the COVID-19 pandemic, the government decided to impose online learning. This makes teachers need to use proper, effective, and efficient teaching materials. One of them is to update the student's worksheet (LKPD) into the form of an electronic Learners ' worksheet (E-LKPD). This research aims to identify the importance of electronic learners ' worksheets (E-LKPD) based on contextual teaching and learning (CTL) approaches in the study of text descriptions during the COVID-19 pandemic. This research uses the survey method using questionnaire or poll as the instrument of research. The poll is created and distributed to 30 respondents via Google form. A questionnaire is distributed to teachers who teach in middle School (SMP). Once data is collected, this study shows that E-LKPD is indispensable in online learning in particular learning to write description text. This is evidenced by most respondents agreeing that the learners ' worksheets (LKPD) write the updated description text into the form of electronic learners ' worksheets (ELKPD). In addition, the teacher agrees that the E-LKPD theme is adjusted to the context (CTL)). Thus, it was concluded that E-LKPD based contextual teaching and learning (CTL) was very useful for learning to write description text in the pandemic COVID-19
\end{abstract}

Keywords: E-LKPD, CTL, text description, COVID-19

\section{INTRODUCTION}

Corona virus is a contagious disease that attacks the respiratory system. The virus initially only attacks animals. However, in 2019 a corona virus was found that also attacks humans. Ilmiyah by Setiawan [1] states that Coronavirus Desease-2019 or abbreviated as COVID-19 is a new type of corona virus that was first discovered in Wuhan, Hubei, China in 2019. This virus is found in all sectors in Indonesia and in the world. Agreeing with this, Mungkasa [2] states that the virus is very wide in society, including in the field of education.

The impact that occurs in the field of education is the application of distance learning both at all levels of education, both kindergarten, elementary, junior high, high school, and college. Distance learning or learning in the network is a distance learning done by using the internet as an intermediary by Isman [3]. When applying social distancing, online learning is useful as a solution to overcoming the problem of learning. According to Kuntarto, [4] online learning is not only accessible through computers, but can also be accessed via mobile phones. This certainly greatly helped the closeness of the study room due to the COVID-19 pandemic.

Curriculum 2013, learning requires students to be more active and contextual. Active is learning that is designed so that students actively argue, discuss, and are able to complete the tasks given by the teacher. Contextual means learning that can be applied and useful in everyday life by Syafrudin [5]. The active and contextual learning will be carried out well if supported by appropriate and adequate media, tools and materials.

One of the Indonesian language lessons that is carried out must be in accordance with the context is the study of writing descriptive text. According to Rohmadi and Nugraheni [6] the description is an essay created to convey the picture objectively so that the reader understands what the writer is conveying. In addition, description text writing skills really need to be researched because learning to write descriptive text is learned in the 2013 Junior High School (SMP) curriculum.

When implementing online learning as it is today, one of the much needed teaching materials is the student worksheet or LKPD. LKPD is teaching material in the form of sheets containing material, summaries, and instructions that must 
be done by students by Hidayatullah [7]. According to Prastowo [8] LKPD can provide learning experiences that are designed and planned systematically to achieve learning objectives. Based on this opinion, it is assumed that a good LKPD can achieve good learning.[ According to Prastowo (8], if seen from its purpose, LKPD is divided into five forms, namely 1) LKPD that helps students find a concept, 2) LKPD that helps students implement and integrate various concepts that have been found, 3) LKPD that functions as a learning guide, 4) LKPD that functions as reinforcement, and 5) LKPD which serves as a practical guide. Therefore, LKPD can be a potential support to assist teachers in teaching descriptive texts.

In learning descriptive text, theme selection is very influential on learning success. According to Wati [9]the contextual teaching material theme will make students become interested in studying the description text. This is consistent with the opinion of Sihotang and Sibuea [10] that the use of contextual textbooks is more effective can improve learning outcomes when compared to using textbooks.

Description text learning using the Contextual Teaching and Learning (CTL) approach is one of the solutions so that the learning of description text which is done online or learn from home becomes more effective. Contextual Teaching and Learning (CTL) approach is a learning strategy that emphasizes the process of student involvement to find the material being studied and connect with real life so students can apply it to real life by Sanjaya in Nurfadilah[11].

Table 1 Results of Teacher's Questionnaire Results on the Importance of LKPD in Learning to Write Description Texts during the COVID-19 Pandemic Period

\begin{tabular}{|l|l|l|l|l|}
\hline Statement & $\begin{array}{l}\text { Very } \\
\text { Agree }\end{array}$ & Agree & $\begin{array}{l}\text { Not } \\
\text { Agree }\end{array}$ & $\begin{array}{l}\text { Very Not } \\
\text { Agree }\end{array}$ \\
\hline $\begin{array}{l}\text { Learning descriptive texts during a pandemic requires more } \\
\text { appropriate teaching material. }\end{array}$ & $46,7 \%$ & $53,3 \%$ & - & - \\
\hline $\begin{array}{l}\text { Description text is very important for students to understand because } \\
\text { it is the first text learning learned in grade VII of junior high school }\end{array}$ & $44,8 \%$ & $56,2 \%$ & - & - \\
\hline $\begin{array}{l}\text { Student worksheets in paper form need to be updated into electronic } \\
\text { form. }\end{array}$ & $43,3 \%$ & $46,7 \%$ & $10 \%$ & - \\
\hline $\begin{array}{l}\text { During the COVID-19 pandemic, E-LKPD really helped students } \\
\text { skillfully write description texts }\end{array}$ & $53,3 \%$ & $43,3 \%$ & $3,4 \%$ & - \\
\hline $\begin{array}{l}\text { Themes on the worksheets provided by students need to be adapted } \\
\text { to the context. }\end{array}$ & $55,2 \%$ & $44,8 \%$ & - & - \\
\hline $\begin{array}{l}\text { The CTL approach is an appropriate approach applied in learning to } \\
\text { write description texts. }\end{array}$ & $20 \%$ & $73,3 \%$ & $6,7 \%$ & - \\
\hline $\begin{array}{l}\text { CTL-based E-LKPD makes it easy for teachers to teach descriptive } \\
\text { texts. }\end{array}$ & $65,5 \%$ & $31 \%$ & $3,5 \%$ & - \\
\hline The teacher has never taught using E-LKPD before. & $35,7 \%$ & $25 \%$ & $25 \%$ & $14,3 \%$ \\
\hline $\begin{array}{l}\text { E-LKPD becomes an alternative when face-to-face learning cannot } \\
\text { be done. }\end{array}$ & $46,7 \%$ & $50 \%$ & $3,3 \%$ & - \\
\hline \begin{tabular}{l} 
E-LKPD that suits the context is important to use in online learning. \\
\hline
\end{tabular} & $56,7 \%$ & $43,3 \%$ & - & - \\
\hline
\end{tabular}

Yulianti [12] and Murtiani [13] prove that the CTL approach is effective for increasing student interest and learning outcomes.

\section{METHOD}

This study uses a survey method using a questionnaire or questionnaire as a research instrument. According to Putri [14], a questionnaire is a tool in data collection which is done by giving a set of questions or written statements to respondents to be answered. The questionnaire was made using Google Form. This instrument is in the form of a question sheet consisting of 30 questions. The question is related to the importance of electronic student worksheets in the COVID-19 pandemic. Questionnaires were distributed to teachers who were teaching description texts in junior high schools. According to Ramadan [15], the questionnaire cannot accommodate knowledge and opinions on the problem under study and many interviews require time to obtain information. Referring to the opinion, the selection of question sheets as an instrument is very appropriate to use.

\section{FINDINGS AND DISCUSSION}

The questionnaire distributed to 30 teachers who taught Indonesian showed the following percentage. 


\subsection{Electronic Student Worksheets for Writing Text Descriptions during the Covid-19 Pandemic Period}

$44.8 \%$ of teachers strongly agree and $56.2 \%$ agree that the description text is a very important text to be mastered by students. This is because the description text is the first text studied in junior high school.

$46.7 \%$ of teachers strongly agree and $53.5 \%$ agree that learning to write descriptive text during the COVID-19 pandemic requires more appropriate teaching material. This indicates the teaching materials used have not been effective and efficient enough to be used. According to Wulandari and Almenda [16] more varied teaching materials can develop and expand the process. This is in agreement with the results of research conducted by Pujiasih [17] in online learning, variations in learning activities are needed because in online learning students and teachers monotonously interact via mobile phones or laptops. So that it takes more varied teaching materials.

E-LKPD is an alternative when face-to-face learning cannot be implemented. The statement responded with a percentage of $46.7 \%$ strongly agree, $50 \%$ agree, and $3.3 \%$ disagree. This indicates that E-LKPD is one of the teaching materials that is quite effective for teachers to teach descriptive text material. Most teachers agree with the statement.

However, in the application of E-LKPD for learning to write description texts, it will be constrained by the lack of teacher experience. This is evidenced by the results of the questionnaire namely, $35.7 \%$ strongly agreed, $25 \%$ agreed, $25 \%$ disagreed, and $14.3 \%$ strongly disagreed that the teacher had never used E-LKPD before. This condition makes the use of E-LKPD must be socialized as early as possible and well explained to Indonesian teachers.

\subsection{Electronic Student Worksheet (E-LKPD) Based on Contextual Teaching and Learning (CTL) in Learning Text Description}

Electronic Student Worksheets (E-LKPD) that fit the important context are used in online learning. The statement responded with a percentage of $56.7 \%$ strongly agree and $43.3 \%$ agree.

The theme of the LKPD provided must be appropriate to the context. $55.2 \%$ of teachers strongly agree and $44.8 \%$ agree. This shows that $100 \%$ of teachers agreed with the LKPD theme in context. Learning in accordance with the context was also approved by Pujiasih [17]in his research. Pujiasih [17] emphasizes on the conclusion of his research that online learning or not face-to-face must be done contextually or really so that it has meaning so that students become characterless.

The Contextual Teaching and Learning (CTL) approach is the right approach applied in learning to write description texts. The statement was responded by the teacher with a percentage of $20 \%$ strongly agree, $73.3 \%$ agree, and $6.7 \%$ disagree. This shows that contextual approach is very important to be applied. Supported by pandemic conditions. Context-based teaching materials will be able to improve the ability to write descriptive text.

CTL-based E-LKPD makes it easy for teachers to teach descriptive texts. CTL-based E-LKPD makes it easy for teachers to teach descriptive texts. The statement responded with a percentage of $65.5 \%$ strongly agree, $31 \%$ agree, and $3.5 \%$ disagree.

\subsection{The Importance of Electronic Student Worksheets (E-LKPD) Based on Contextual Teaching and Learning}

(CTL) in Learning to Write Text Descriptions during the Covid-19 Pandemic Period 43.3\% strongly agree, 46.7\% agree, and $10 \%$ disagree. This shows that in general the teacher agrees if the student worksheet (LKPD) is updated in the electronic form. Sari, Nurhayati, and Soetopo [18] in their research concluded that the use of electronic LKPD can improve students' writing abilities. $53.3 \%$ strongly agree, $43.3 \%$ agree, and $3.4 \%$ disagree. Based on this, it is seen that teachers tend to agree because more than $50 \%$ agree that the use of E-LKPD during the COVID-19 pandemic really helped improve the skills of writing descriptive texts.

\section{CONCLUSION}

Based on the results of the study concluded that E-LKPD based on the Contextual Teaching and Learning approach is important to be used in learning to write descriptive text during the COVID-19. E-LKPD can simplify and narrow space and time so that learning becomes more effective. In addition, electronic LKPD can also be an interesting tool when student interest in learning is now increasingly diminishing.

\section{ACKNOWLEDGMENT}

Finally, I am finished this paper with the support everyone who follows me. And I am deeply indebted to my supervisor, Dr. Tressyalina, M.Pd., for warm support, inspiration and thoughtful guidance. And also to my beloved family and friends who never stop supporting me. This paper is far from perfect, but it is expected that it will be useful not only for the researcher, but also for the readers. For this reason, constructive thoughtful suggestion and critics are welcomed. Thank you. 


\section{REFERENCES}

[1] Setiawan. Adib Rifqi. Lembar Kegiatan Literasi Saintifik untuk Pembelajaran Jarak Jauh Topik Penyakit Coronavirus 2019 (COVID-19). Jurnal Edukatif, 2(1), hal 28-37. 2020.

[2] Mungkasa, Oswar. Bekerja dari Rumah (Work From Home/WFH) : Menuju Tatanan Baru Era Pandemi COVID

19. The Indonesia Journal of Development Planning, Vol 4 (2). 2020

[3] Isman, Mhd. Pembelajaran Moda dalam Jaringan (Moda Daring). The Progressive and Fun Education Seminar. Universitas Muhammadyah Surakarta. 2016.

[4] Kuntarto, Eko. Keefektifan Model Pembelajaran Daring dalam Perkuliahan Bahasa Indonesia di Perguruan Tinggi. Jurnal Indonesian Leanguage and Literatur, 3(1). 2017

[5] Syafrudin, Albitar Septian. Implementasi Pembelajaran Daring untuk Meningkatkan Mutu Pendidikan sebagai Dampak Diterapkannya Social Distancing. Metalingua Jurnal Pendidikan Bahasa dan SastraIndonesia,5 (1). 2020

[6] Rohmadi, Muhammad dan Nugraheni, Anindya Sri. Belajar Bahasa Indonesia : Upaya Terampil Berbicara dan Menulis Karya Ilmiah. Surakarta: Cakrawala Media. 2011

[7] Hidayatullah, Fariz, Sumarti, \& Ariyani, Farida. Pengembangan LKPD Menulis Teks Eksposisi Berbasis Model Discovery Learning Siswa Kelas VIII. J-Simbol (Bahasa, Sastra, dan Pembelajarannya), Mei 2019.

[8] Prastowo, Andi. Panduan Kreatif Membuat Bahan Ajar Inovatif. Yogyakarta: Diva Press. 2011.

[9] Wati, Syafrida. Pengembangan Modul Teks Deskripsi Berbasis Kontekstual untuk Siswa Kelas X SMA Negeri 1 Gunung Meriah Aceh Singkil. 2018.

[10] Sihotang, Ahmad Usman dan Sibuea, Abdul Muin. Pengembangan Buku Ajar Berbasis Kontekstual dengan Tema "Sehat itu Penting". Medan: Universitas Negeri Medan. http://www.e-journal.com. 2013.
[11] Nurfadilah, Agung Arif. "Penggunaan Model Contextual Teaching and Learning (CTL) untuk Meningkatkan Hasil Belajar Siswa dalam Pembelajaran IPS Kelas IV pada Materi Mengenal Unsur-unsur Peta". Skripsi. Bandung: Fakultas Keguruan dan Ilmu Pendidikan UNPAS. 2016.

[12] Yulianti, D., M. Lestari, dan A. Yulianto. Penerapan Jigsaw Puzzle Competition dalam Pembelajaran Kontekstual untuk Meningkatkan Minat dan Hasil Belajar Fisika Siswa SMP. Jurnal Pendidikan Fisika Indonesia, 6, 84-89. 2010.

[13] Murtiani, A. Fauzan dan R. Wulan. "Penerapan Pendekatan Contextual Tecahing dan Learning (CTL) Berbasis Lesson Study dalam Meningkatkan Kualitas Pembelajaran Fisika di SMP Negeri Kota Padang". Jurnal Penelitian Pembelajaran Fisika, 1, 1-12. 2012.

[14] Putri, Indira Arifiana. "Identifikasi Keterampilan Berpikir Kritis Siswa Berdasarkan Literasi Match-Ict dalam Menyelesaikan Soal Integral Tentu Ditinjau dari Tingkat Kemampuan Metakognisi". Skripsi. Jember. Fakultas Keguruan dan Ilmu Pendidikan Universitas Jember. 2017.

[15] S, Ramadan, E Sukma, dan V Indriyani. Environmental Education and Disaster Mitigation Truogh Language Learning. The 1st International Converence on Environmental Sciences (ICES2018) 2018.

[16] Wulandari, Mega dan Truly, Almenda. Technology for English Language Learning. Yogyakarta: Santa Dharma University Press. 2020.

[17] Pujiasih, Erna. Membangun Generasi Emas dengan Variasi Pembelajara Online di Masa Pandemi COVID-19. Ideguru: Jurnal Karya Ilmiah Guru, 5 (1) , Edisi Khusus KBM Pandemi COVID-19. 2020

[18] Sari, Fiqi Nurmanda, Nurhayati, \& Soetopo. Pengembangan Lembar Kerja Peserta Didik (LKPD) Elektronik Teks Cerita Pendek Berbasis Budaya Lokal. Palembang. Seminar Nasional Universitas Sriwijaya. 2017 